\title{
Soluble Salts in a Temperate Glacier
}

\author{
By EVILLE GORHAM, Freshwater Biological Association, Ambleside, England
}

(Manuscript received November 27, I957; revised February 8, 1958)

In a recent paper on gas enclosures in a temperate glacier (Storbreen in the Jotunheim district of Norway) Coachman, Hemmingsen and Scholander (Tellus, 1956) report some specific conductivity and $\mathrm{pH}$ measurements made on melted samples as chemical tests of ice purity (conductivity giving some indication of the amount of dissolved ions). In April I957 the writer accompanied the first two of these authors (to whom he is most grateful for their kindness and hospitality) in order to collect ice samples from approximately the same localities for further chemical studies. The ice was shaved with clean metal instruments into polyethylene bottles, whose cleanliness had been checked by conductimetric examination of distilled water stored in them for some days, and the samples were then transported to England for analysis. As a preliminary, electrometric measurements of $\mathrm{pH}$ and specific conductivity were again made, with the results shown in Table $I$.

The present series of ice samples gave ranges of $\mathrm{pH} 5.72-5.96$ and $x_{20} \cdot 10^{-6}$ I.3-2.6. The conductivity values were lowered appreciably, and the $\mathrm{pH}$ values raised, by about five minutes bubbling with air in which the carbon dioxide had been reduced by passage through soda-asbestos, the air being subsequently led through a sintered glass disc into distilled water. Upon comparison of these values with some for ordinary distilled water (also shown in Table I), it is clear that the ice is in fact extremely pure. Sodium and potassium con- centrations (not very accurately estimated because near the limit of detection) are very low indeed, in spite of some noticeable-but very slight-soil contamination. Calcium is not measurable by the versenate-ammonium purpurate method in $100 \mathrm{ml}$ aliquots. Dissolved silica (measured spectro-photometrically) is barely detectable, at about $0.005-0.010$ part per million of $\mathrm{SiO}_{2}$. Both ammonia and nitrate ions (again measured spectro-photometrically) also exhibit very low concentrations in the ice samples, the former averaging 0.02 and the latter 0.0 I part per million of nitrogen.

Sample 6, which was quite turbid with finc soil when collected and stood in contact with it for some weeks, shows by its low conductivity that mineral material is dissolved very slowly from soils in this area. For this reason the streams and rivers, exemplified by samples 7 and 8 , are also low in salts as compared with most fresh waters.

Analysis of the winter's snowfall $(3-4 \mathrm{~m}$ profile sampled at the same time) gave much higher conductivity, sodium and potassium values than those for glacier ice; and the concentration of nitrogen was also somewhat higher. Furthermore, the conductivity range for monthly precipitation samples at Vågåmo to the northeast is Io- 56 over the months October to March (Brodin I956, I957), evell the minimum value being considerably above that for the glacier ice; while the average concentrations of sodium, potassium, ammonia and nitratc are also much greater than in Stor- 
breen ice. Unless it be supposed that formerly the precipitation falling on the glacier was almost devoid of salts, a rather unlikely possibility, it would seem necessary to assume some loss of salts in the course of ice formation. In a wasting temperate glacier like Storbreen such a loss might well occur during the period of summer melting, when much of the accumulated winter snow must disappear even above the firn line. It is of course well known that snow and ice deposits consist of smaller or larger crystals of pure water, separated by thin films of inter-crystalline brines which contain any soluble impurities (BucHanan I908); and it seems reasonable to suppose that during the melting and consolidation processes these brines may be largely washed away, the annual ice layer being formed from those ice kernels which fail to dissolve completely through the summer (cf. RenAud 1949).
The low optical density values given in Table I testify to the purity of the ice as regards soluble organic matter. They were obtained in a Unicam SP 500 spectro-photometer with glass cells, on samples collected in glass bottles and subsequently filtered through a no. 3 sintered glass disc of average pore size about $20-30 \mu$. This treatment did not remove all the particulate material, as some light scattering was still apparent in the samples.

In conclusion it may be remarked that among the chemical properties investigated there is no evident variation associated with the age of the samples, such as was found by Conchman ET AL. in the case of gas pressure and oxygen content of the air bubbles in the ice, the former increasing and the latter decreasing in the older ice toward the bottom of the glacier.

Table I. Chemical characteristics of some Norwegian ice, snow and stream waters collected in the Jotunheim mountains, April 1957.

\begin{tabular}{|c|c|c|c|c|c|c|c|c|c|c|}
\hline \multirow[t]{3}{*}{$\begin{array}{l}\text { Sample } \\
\text { No. }\end{array}$} & \multirow[t]{2}{*}{ Description of sample } & \multirow{2}{*}{\multicolumn{2}{|c|}{$\begin{array}{c}\text { Conductivity } \\
\text { before after } \\
\text { co }_{\mathbf{2}} \text {-free aeration } \\
\text { (micromhos, } \\
20^{\circ} \text { C) }\end{array}$}} & \multirow{2}{*}{\multicolumn{2}{|c|}{$\begin{array}{c}\mathrm{pH} \\
\text { before after } \\
\text { CO }- \text { free } \\
\text { aeration }\end{array}$}} & \multirow{2}{*}{$\mid \begin{array}{c}\text { Optical } \\
\text { Density } \\
\left(\log \frac{I 0}{I} \text { at }\right. \\
320 \mathrm{~m} \mu, \\
10 \mathrm{~cm} \text { cells })\end{array}$} & \multirow[t]{2}{*}{$\begin{array}{r}\text { So- } \\
\text { dium }\end{array}$} & \multirow{2}{*}{\multicolumn{2}{|c|}{ 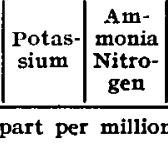 }} & \multirow{2}{*}{$\begin{array}{r}\text { Ni- } \\
\text { trate } \\
\text { Nitro } \\
\text { gen }\end{array}$} \\
\hline & & & & & & & & & & \\
\hline & $\begin{array}{l}\text { Distilled water, ordinary quality } \\
\text { from metal still } \ldots \ldots \ldots \ldots \ldots\end{array}$ & 1.8 & I. I & $5 \cdot 72$ & 6.98 & nil & nil & nil & nil & nil \\
\hline I & Ice from foot of glacier ........ & $1 \cdot 3$ & I.o & $5 \cdot 72$ & 6.12 & 0.057 & 0.02 & 0.02 & 0.02 & 0.01 \\
\hline 2 & Ice, c. $600 \mathrm{~m}$ from foot of glacier & 2.6 & 2.2 & 5.96 & $6.4^{8}$ & 0.045 & 0.08 & 0.04 & 0.02 & 0.01 \\
\hline 3 & " $1,300 \mathrm{~m}$ & 1.7 & I.5 & $5 \cdot 79$ & $6 \cdot 34$ & 0.024 & 0.06 & 0.03 & 0.02 & 0.01 \\
\hline 4 & $" \quad 2,000 \mathrm{~m}$ & 1.6 & I.I & $5 \cdot 77$ & 6.42 & 0.043 & 0.02 & 0.03 & $0.0 \mathrm{I}$ & 0.01 \\
\hline 5 & Snow $" 2,000 \mathrm{~m} "$ & 6.5 & 6.I & 4.98 & $5 \cdot 4^{2}$ & 0.032 & 0.22 & 0.08 & 0.03 & 0.03 \\
\hline & $\begin{array}{l}\text { Melted snow, percolating frost }- \\
\text { heaved hillside soil } \ldots \ldots \ldots \ldots \ldots\end{array}$ & $5 \cdot I$ & $4 \cdot 3$ & $5 \cdot 34$ & 5.80 & 0.015 & not & not & not & not \\
\hline 7 & Water from stream in valley, & & & & & & done & done & done & done \\
\hline 8 & draining Leirvatn $\ldots \ldots \ldots \ldots$ & I 3.9 & I 4.1 & 6.35 & $7 \cdot 44$ & 0.017 & 0.43 & 0.22 & 0.06 & 0.04 \\
\hline & 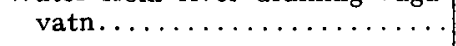 & 24.2 & $24 \cdot 2$ & 6.70 & $7 \cdot 54$ & not done & 0.66 & 0.53 & 0.01 & 0.003 \\
\hline
\end{tabular}

\section{REFER E N C E S}

Brodin, G., I956 and I957: Current data on the chemical composition of air and precipitation. Tellus 7 and 8 , quarterly appendices.

Buchanan, J. Y., I908: Ice and its natural history. Proc. Roy. Insin G.B. 19, 243-276.
Conchman, L. K., Hemmingsen, E., and Scholander, P. F., 1956: Gas enclosures in a temperate glacier. Tellus 8, 4IS-423.

Renaud, A., I949: A contribution to the study of the glacier grain. J. Glaciol. I, 320-324. 